\title{
MITIGASI BANJIR STRUKTURAL MENGGUNAKAN MODEL HEC-RAS DAN GEO-STUDIO PADA WILAYAH SUNGAI TOBA-ASAHAN, SUMATERA UTARA
}

\author{
Rian Mantasa Salve Prastica ${ }^{1)}$, Aditya Widyatmoko(2), Rezky Kurniawan ${ }^{3)}$ \\ 1) Departemen Teknik Sipil, Universitas Gadjah Mada, Yogyakarta, 55281 \\ ${ }^{2,3)}$ Program Studi Sarjana Terapan Teknik Pengelolaan dan Pemeliharaan Infrastruktur \\ Sipil, Universitas Gadjah Mada, Yogyakarta, 55281 \\ Email: rian.mantasa.s.p@ugm.ac.id ${ }^{1)}$, aditya.widyatmoko@mail.ugm.ac.id ${ }^{2)}$, \\ $\underline{\text { rezky.kurniawan@mail.ugm.ac.id }}^{3)}$
}

DOI: http://dx.doi.org/10.29103/tj.v11i2.519

(Received: April 2021 / Revised: August 2021 / Accepted: August 2021)

\begin{abstract}
Abstrak
Permasalahan banjir menjadi isu utama di Indonesia dan di dunia. Strategi manajemen pengendalian banjir dapat berupa upaya mitigasi struktural dan non-struktural. Adanya perkembangan penelitian menyebutkan bahwa mitigasi non-struktural memiliki dampak yang baik dalam mereduksi banjir. Penelitian ini mengambil studi kasus di daerah studi yaitu Wilayah Sungai Toba-Asahan, tepatnya di Sungai Silau. Apakah mitigasi struktural dalam pengendalian banjir signifikan? Analisis kapasitas hidrolika menggunakan software HEC-RAS adanya penurunan limpasan banjir dari kondisi eksisting ke kondisi skenario normalisasi sungai. Begitu pula nilai safety factor lereng sungai pada lokasi tinjauan menggunakan software Geo-Studio yang naik sebesar $139 \%$. Opsi usulan desain bendungan urugan juga dapat mereduksi banjir sebesar 24,83\%. Sehingga, dapat disimpulkan bahwa mitigasi struktural signifikan dalam pengendalian banjir. Namun, mitigasi struktural tidak bersifat sustainable bagi pemangku kepentingan, sehingga perlu ada skenario simulasi menggunakan mitigasi non-struktural.
\end{abstract}

Kata kunci: pengendalian banjir, mitigasi struktural, mitigasi non-struktural, flood routing

\begin{abstract}
The problem of flooding is a major issue in Indonesia and in the world. Flood control management strategies can take the form of structural and non-structural mitigation measures. The development of research states that non-structural mitigation has a good impact in reducing flooding. This research took a case study in the study area, namely the Toba-Asahan River Basin, to be precise in the Silau River. Is structural mitigation in flood control significant? Analysis of hydraulic capacity using HEC-RAS software shows a decrease in flood runoff from existing conditions to river normalization scenario conditions. Likewise, the river slope safety factor value at the review location using Geo-Studio software increased by $139 \%$. The proposed option for embankment dam design can also reduce flooding by $24.83 \%$. Thus, it can be concluded that structural mitigation is significant in flood control. However, structural mitigation is not sustainable for stakeholders, so there needs to be a simulation scenario using nonstructural mitigation.
\end{abstract}

Keywords: flood management, structural mitigation, non-structural mitigation, flood routing

Mitigasi Banjir Struktural Menggunakan Model Hec-Ras dan Geo-Studio Pada Wilayah Sungai Toba-Asahan, Sumatera Utara - Rian Mantasa Salve Prastica, Aditya Widyatmoko, Rezky Kurniawan 


\section{Latar Belakang}

Banjir selalu menjadi topik 'panas' dalam pengelolaan sumber daya air (Wedawatta et al., 2016). Hal ini sama halnya dengan kekurangan air dengan bencana kekeringan (Shenava and Shourian, 2018), kelebihan air dengan adanya bencana banjir menjadi perhatian banyak pemangku kepentingan (Stephenson, Finlayson and Morel, 2018). Satu dekade terakhir, banyak penelitian terkait pengendalian banjir baik struktural (Alam et al., 2018) maupun non-struktural tidak hanya di Indonesia (Prastica, Apriatresnayanto and Marthanty, 2019), tetapi juga di dunia (Price and Vojinovic, 2008; Broekhuizen et al., 2019). Penelitian terkait mitigasi struktural melakukan klaim bahwa mitigasi dengan cara ini dinilai lebih efektif dalam reduksi volume banjir (Andersen et al., 2011; Lempérière, 2017; Ezzine et al., 2020). Di sisi lain, mitigasi non-struktural juga perlu dilakukan dan diklaim sebagai cara efektif dibandingkan mitigasi struktural (Mohit and Sellu, 2013; Bang, Miles and Gordon, 2019; Farooq, Shafique and Khattak, 2019).

Banyaknya perdebatan dan perbedaan karakteristik daerah satu dengan yang lainnya membuat strategi manajemen pengendalian banjir berbeda penilaiannya. Banyak negara berkembang yang masih mengupayakan mitigasi struktural sebagai upaya pengendalian banjir yang terjadi setiap tahunnya (Lin, Shaad and Girot, 2016). Apakah pengedalian banjir dengan metode mitigasi struktural ini masih signifikan kontribusinya terhadap pengurangan dampak banjir terhadap lingkungan? Penelitian ini akan menjawab pertanyaan tersebut dan memberikan rekomendasi strategi mitigasi bencana banjir dengan karakteristik daerah yang sama.

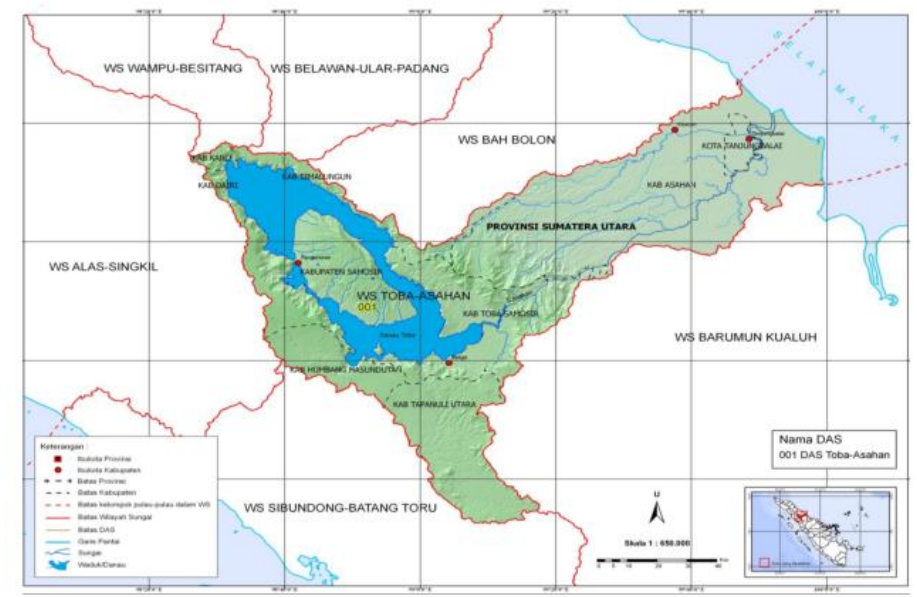

Gambar 1 Wilayah Sungai Toba-Asahan, Sumatera Utara

Penelitian ini mengambil studi kasus daerah Wilayah Sungai (WS) TobaAsahan, sesuai Gambar 1 (Balai Wilayah Sungai (BWS) II, 2013). Daerah ini menjadi salah satu wilayah sungai strategis nasional di Provinsi Sumatera Utara berdasarkan Keputusan Presiden Republik Indonesia Nomor 12 Tahun 2012. Isuisu strategis terkait permasalahan yang menjadi prioritas pada WS ini adalah kerusakan hutan, banjir (Dinas Tata Kota Kabupaten Asahan, 2012; Sukmana et al., 2013), kualitas air sungai, pengingkatan erosi dan sedimentasi di sungai, kelestarian lingkungan Danau Toba (Zevri and Isma, 2021), dan kekeringan dan kekurangan air irigasi (Lukman, 2017). Prioritas banjir yang menjadi isu pada WS ini akan menjadi arah penelitian utama.

Mitigasi Banjir Struktural Menggunakan Model Hec-Ras dan Geo-Studio Pada Wilayah Sungai Toba-Asahan, Sumatera Utara - Rian Mantasa Salve Prastica, Aditya Widyatmoko, Rezky Kurniawan 
Di Indonesia, penelitian terkait mitigasi struktural telah banyak dilakukan. Mitigasi ini identik dengan pembangunan infrastruktur seperti pembangunan bendungan (Saputra, Saputro and Prastica, 2021), normalisasi sungai (Rubinato et $a l ., 2019)$, dan lain-lain. Di sisi lain, mitigasi non-struktural masih belum dominan, namun sudah mulai diterapkan. Dengan adanya isu infrastruktur hijau, banyak penelitian yang mengarah ke mitigasi non-struktural (Braga et al., 2018). Tetapi, tidak semua daerah memiliki karakteristik yang cocok untuk diterapkan mitigasi non-struktural, dalam hal ini adalah green infrastructure. Banyak yang masih efektif bila penanganan banjir dilakukan dengan mitigasi struktural seperti wilayah rural dan sub-urban.

\section{Metode Penelitian}

Mitigasi struktural dapat dilakukan dengan banyak cara. Salah satu yang paling cepat dilakukan penilaian adalah normalisasi sungai (Cojoc, Romanescu and Tirnovan, 2015). Dengan dasar ilmu teknik sipil, kapasitas hidrolika bila dibandingkan dengan volume debit banjir yang terjadi perlu dilakukan normalisasi bila volume kapasitas hidrolika tidak bisa menampung debit banjir yang terjadi. Analisis sederhana dalam memahami konsep ini adalah kasus sungai alam merupakan aliran tidak seragam atau non-uniform flow (Chow et al., 1998). Dalam menyelesaikan analisis hidrolika pada sungai, profil muka air dihitung dengan cara membagi saluran menjadi bagian saluran-saluran pendekberisi cross section sungai secara bertahap dari hulu ke hilir, yang biasa disebut dengan direct step method. Gambar 2 (Chow et al., 1998) menunjukkan bagian saluran sepanjang $\Delta \mathrm{x}$, dengan tinggi energi di masing-masing ujung penampang, di mana dapat dirumuskan pada Persamaan (1), Persamaan (2), dan Persamaan (3).

$$
\begin{aligned}
& S_{0} \Delta x+y_{1}+\alpha_{1} \frac{v_{1}^{2}}{2 g}=y_{2}+\alpha_{2} \frac{v_{2}^{2}}{2 g}+S_{f} \Delta x \\
& \Delta x=\frac{E_{2}-E_{1}}{S_{0}-S_{f}}=\frac{\Delta E}{S_{0}-S_{f}} \\
& E=y+\alpha \frac{v^{2}}{2 g}
\end{aligned}
$$

di mana, y adalah Kedalaman aliran (m), V adalah Kecepatan rata-rata (m/dt), $\alpha$ adalah Koefisien energi, $S_{0}$ adalah Kemiringan dasar dan $S_{\mathrm{f}}$ adalah Kemiringan geser

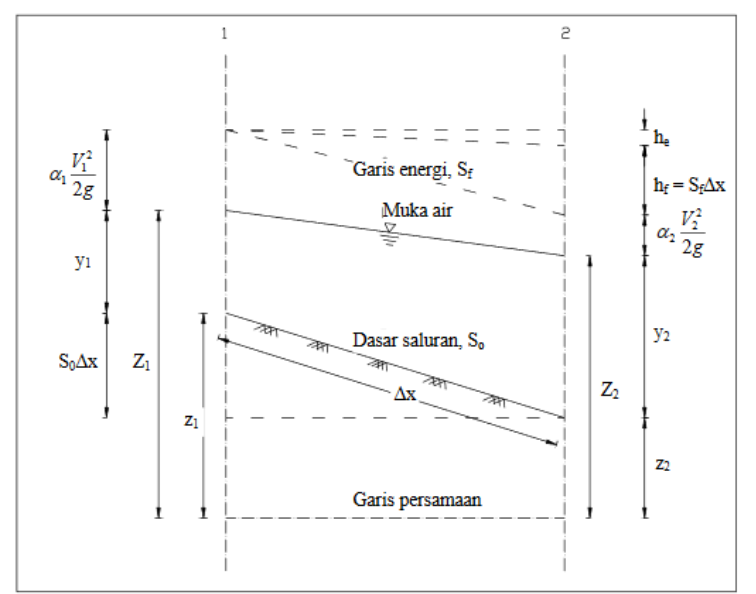

Gambar 2 Bagian saluran sepanjang $\Delta \mathrm{x}$ (Chow et al., 1998)

Mitigasi Banjir Struktural Menggunakan Model Hec-Ras dan Geo-Studio Pada Wilayah Sungai Toba-Asahan, Sumatera Utara - Rian Mantasa Salve Prastica, Aditya Widyatmoko, Rezky Kurniawan 
Dalam kasus seperti Gambar 2, berlaku juga persamaan Manning pada Persamaan (4) di mana R adalah jari-jari hidrolis. Sedangkan besarnya nilai $v$ pada kedua penampang dapat dianalisis menggunakan persamaan (5).

$$
\begin{aligned}
& S_{f}=\frac{n^{2} v^{2}}{2,22 R^{4 / 3}} \\
& v_{1}=\frac{Q}{A_{1}} ; v_{2}=\frac{Q}{A_{2}}
\end{aligned}
$$

di mana, $v_{1}$ adalah Kecepatan aliran pada penampang $1(\mathrm{~m} / \mathrm{dt}), v_{2}$ adalah Kecepatan aliran pada penampang $2(\mathrm{~m} / \mathrm{dt})$, Q adalah Debit aliran $\left(\mathrm{m}^{3} / \mathrm{dt}\right), \mathrm{A}_{1}$ adalah Luas basah penampang $1\left(\mathrm{~m}^{2}\right)$ dan $\mathrm{A}_{2}$ adalah Luas basah penampang $2\left(\mathrm{~m}^{2}\right)$

Analisis hidrolika pada penelitian ini akan didukung menggunakan software HEC-RAS untuk memberikan visualisasi profil muka air (Kumar et al., 2019; Abdi, Endreny and Nowak, 2020) saat banjir dan setelah normalisasi dalam upaya mitigasi struktural. Selain faktor hidrolika sungai, analisis penelitian ini mempertimbangkan nilai safety factor (Saputra, Saputro and Prastica, 2021) ruas sungai sebelum dan sesudah skenario pemodelan hidrolika.

Tabel 1 Data hujan pada wilayah studi

\begin{tabular}{cccccc}
\hline Tahun & $\begin{array}{c}\text { Stasiun Klimatologi } \\
\text { Wilayah I - Medan }\end{array}$ & $\begin{array}{c}\text { Stasiun } \\
\text { Meteorologi } \\
\text { F. L. Tobing }\end{array}$ & $\begin{array}{c}\text { Stasiun } \\
\text { Klimatologi } \\
\text { Kualanamu }\end{array}$ & $\begin{array}{c}\text { Stasiun } \\
\text { Meteorologi } \\
\text { Aek Godang }\end{array}$ & $\begin{array}{c}\text { Stasiun Kota } \\
\text { Tanjung Balai }\end{array}$ \\
\cline { 2 - 6 } 2008 & $(\mathrm{~mm})$ & $(\mathrm{mm})$ & $(\mathrm{mm})$ & $(\mathrm{mm})$ & $(\mathrm{mm})$ \\
\hline 2009 & 82 & 162 & 82,4 & 97,6 & 110,6 \\
\hline 2010 & 85 & 172 & 115,4 & 100,5 & 134,8 \\
\hline 2011 & 85 & 171 & 72,4 & 98,1 & 321 \\
\hline 2012 & 97 & 269 & 82,5 & 156,8 & 402 \\
\hline 2013 & 100 & 229 & 93 & 213,6 & 165 \\
\hline 2014 & 98 & 176,1 & 88,6 & 90,1 & 265 \\
\hline 2015 & 112 & 229,5 & 107,4 & 597,9 & 337 \\
\hline 2016 & 106,7 & 181,1 & 107 & 466,9 & 258 \\
\hline 2017 & 158,5 & 189,5 & 101,6 & 168,4 & 256 \\
\hline
\end{tabular}

Data hujan yang digunakan pada penelitian ini bersumber dari Badan Meteorologi Klimatologi dan Geofisika (BMKG), yang terdiri dari lima stasiun hujan yang berada di sekitar daerah aliran sungai (DAS), yaitu Stasiun Klimatologi Kualanamu, Stasiun Meteorologi F. L. Tobing, Stasiun Klimatologi Wilayah I Medan, Stasiun Meteorologi Aek Godang, dan Stasiun Kota Tanjung Balai, sebagaimana tertera pada Tabel 1 .

Analisis curah hujan rata-rata menggunakan Metode Thiessen (Piotrowski, Osuch and Napiorkowski, 2019) seperti Gambar 3. Berdasarkan analisis ini, persentase masing-masing DAS terdampak stasiun hujan adalah 0,7\%, 19\%, 26\%, $1,4 \%$, dan $54 \%$, secara berurutan sesuai penyebutan stasiun sebelumnya. Dari hasil analisis uji frekuensi dan kecocokan distribusi hujan, pola distribusi hujan yang dihasilkan pada DAS adalah seperti Gambar 4 dan Gambar 5.

Selanjutnya, analisis debit banjir dilakukan menggunakan hidrograf satuan sintesis (HSS) Nakayasu (Frans and Halema, 2019). Debit banjir yang dihasilkan dari HSS ini akan menjadi basis untuk pemodelan hidrolika menggunakan HECRAS.

Mitigasi Banjir Struktural Menggunakan Model Hec-Ras dan Geo-Studio Pada Wilayah Sungai Toba-Asahan, Sumatera Utara - Rian Mantasa Salve Prastica, Aditya Widyatmoko, Rezky Kurniawan 
Penggunaan HEC-RAS sebagai alat pemodelan water engineering sudah banyak dilakukan oleh penelitian sebelumnya, baik di Indonesia maupun di dunia. HEC-RAS menjadi alat bantu praktis bagi banyak pemangku kepentingan untuk menilai kondisi hidrolika suatu saluran sungai, terutama dalam pengendalian bencana banjir. HEC-RAS menyediakan visualisasi yang baik dalam analisis hidrolika dari segi graphical user interface, analisis grafik, manajemen penyimpanan data, serta bentuk pelaporan hasil analisis dalam satu perangkat lunak yang terintegrasi.

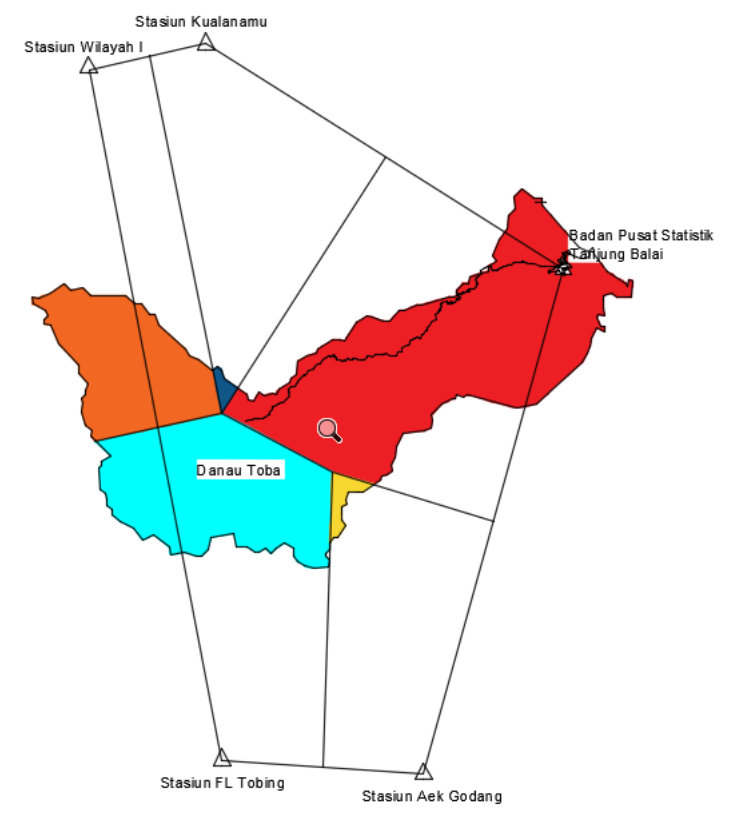

Gambar 3 Metode Thiessen dalam analisis hujan daerah studi

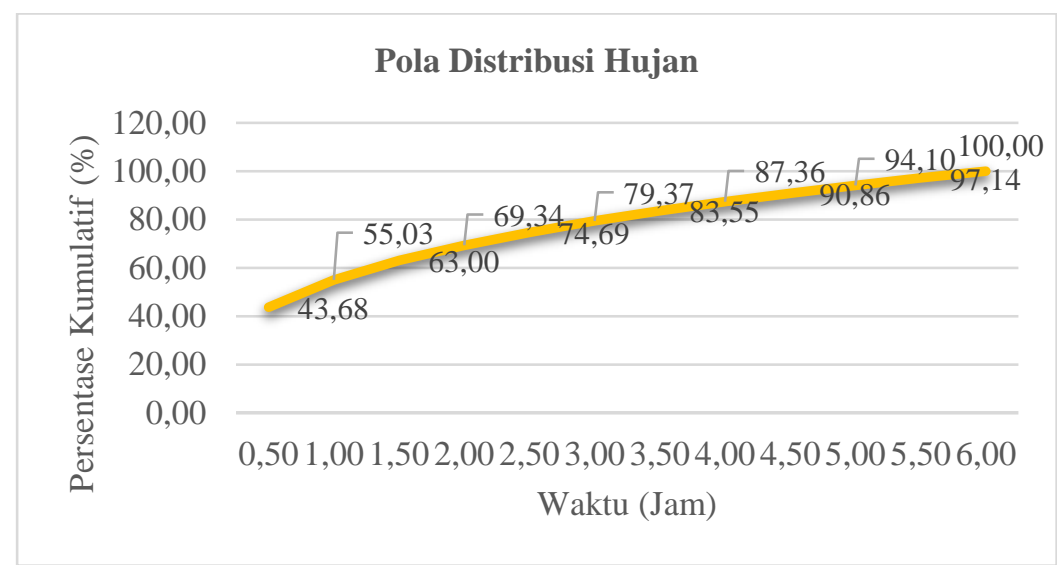

Gambar 4 Pola distribusi hujan

Lebih jauh lagi, analisis stabilitas lereng sungai yang ditinjau akan dianalisis menggunakan software Geo-Studio (GEO-SLOPE International Ltd., 2012). Prinsip yang digunakan dalam mendapatkan nilai safety factor dengan metode irisan (method of slice). Pada Gambar 6 (a) (Zhao, Tong and Lü, 2014), metode ekuilibrium membagi bidang yang akan dianalisis berupa irisan ke beberapa bagian sebanyak $n$ irisan dan gaya-gaya yang bekerja pada bidang irisan digambarkan pada

Mitigasi Banjir Struktural Menggunakan Model Hec-Ras dan Geo-Studio Pada Wilayah Sungai Toba-Asahan, Sumatera Utara - Rian Mantasa Salve Prastica, Aditya Widyatmoko, Rezky Kurniawan 
Gambar 6 (b) (Zhao, Tong and Lü, 2014) dengan beberapa komponen gaya seperti beban bidang $\left(W_{i}\right)$, gaya gempa horizontal $\left(Q c_{i}\right)$, beban horizontal dan vertikal $\left(Q x_{i}\right.$, $\left.Q y_{i}\right)$, tekanan air $\left(U_{i}\right)$, gaya antaririsan $\left(E_{i}, X_{i}, E_{i+1}, X_{i+1}\right)$, gaya normal $\left(N_{i}\right)$, dan kekuatan geser $\left(T_{i}\right)$ pada permukaan. Sketsa ini merupakan pengembangan baru metode irisan dibandingkan metode konvensional yang biasa digunakan pada konsep dasar Geo-Studio (Prastica, Apriatresnayanto and Marthanty, 2019).

Berdasarkan analisis kondisi eksisting profil muka air dan stabilitas lereng sungai tinjauan, pemodelan mitigasi dengan skenario normalisasi dilakukan dan dilakukan analisis yang sama dengan kondisi eksisting. Hasil akhir dari analisis ini lalu dikomparasi dengan kondisi eksisting untuk mendapatkan tingkat pengaruh normalisasi terhadap profil muka air dan stabilitas lereng pada sungai tinjauan. Hasil ini kemudian menjadi parameter identifikasi tingkat signifikansi mitigasi struktural dalam pengendalian banjir. Weakness dari upaya struktural kemudian disusun berdasarkan literature review untuk mendapatkan rekomendasi strategi mitigasi yang sesuai dan dinilai efektif.

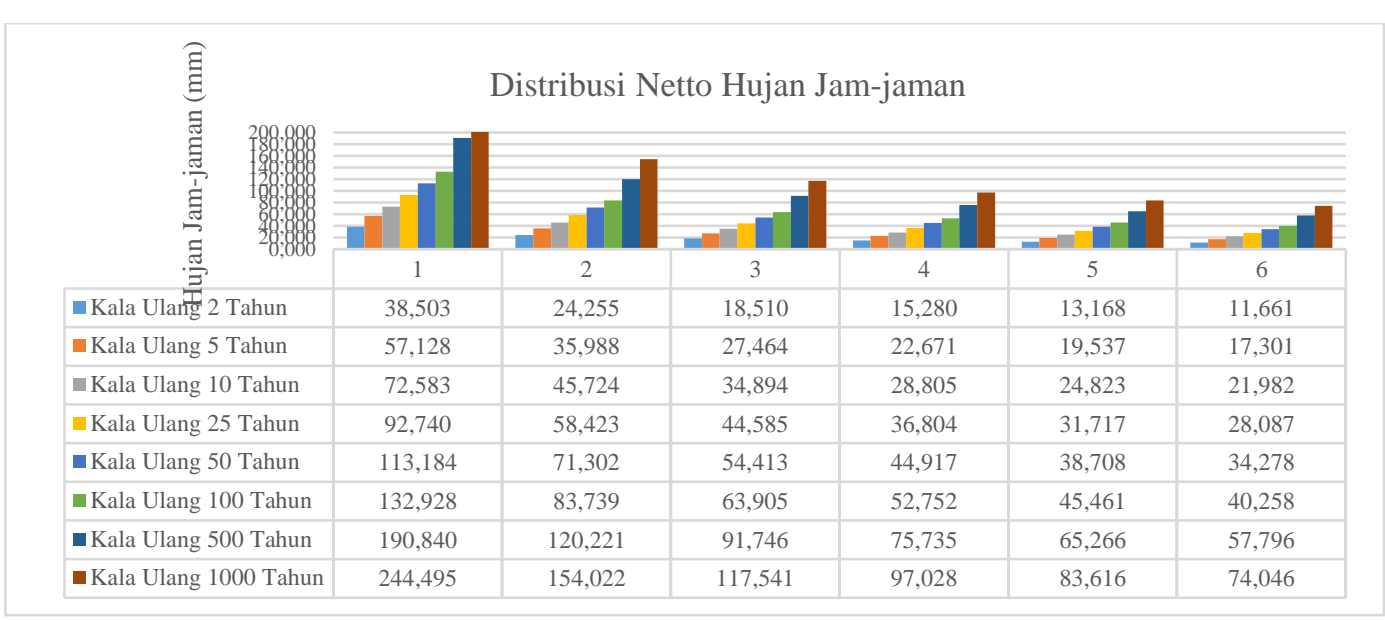

Gambar 5 Distribusi netto hujan jam-jaman

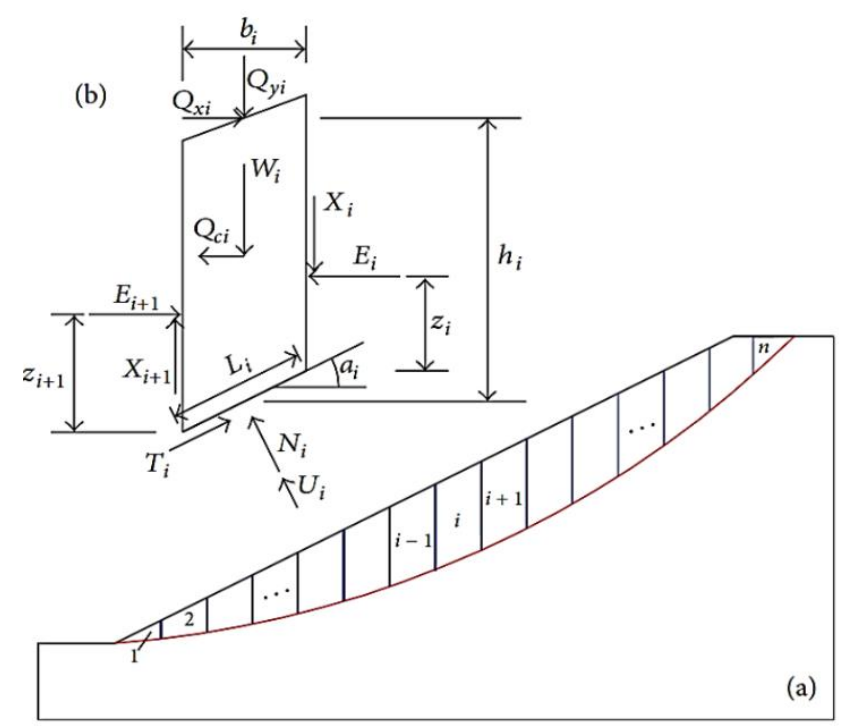

Gambar 6 Sketsa cross section dan gaya yang bekerja pada metode irisan (Zhao, Tong and Lü, 2014)

Mitigasi Banjir Struktural Menggunakan Model Hec-Ras dan Geo-Studio Pada Wilayah Sungai Toba-Asahan, Sumatera Utara - Rian Mantasa Salve Prastica, Aditya Widyatmoko, Rezky Kurniawan 


\section{Hasil dan Pembahasan}

Debit banjir pada analisis ini menggunakan hidrograf satuan sintesis (HSS) Nakayasu. Dengan data awal luas daerah pengaliran sungai sebesar $7225,45 \mathrm{~km}^{2}$, panjang sungai utama $145 \mathrm{~km}$, dan $\mathrm{R}_{0}$ (hujan satuan) $1 \mathrm{~mm}$, grafik hidrograf HSS Nakayasu dapat dilihat hasilnya pada Gambar 7. Debit puncak yang terjadi pada hidrograf pada masing-masing kala ulang menjadi input data pada program HECRAS ketika melakukan analisis profil aliran pada sungai tinjauan. Setelah itu, debitdebit analisis ini menjadi dasar pula dalam pemodelan skenario mitigasi pengendalian banjir secara struktural yang dilakukan pada penelitian ini.

Analisis kondisi hidrolika eksisting dilakukan menggunakan data sekunder hidrolika pada Sungai Silau (Harahap, 2013). Dari hasil analisis, didapatkan debit banjir saluran eksisting sebesar 53.633,65 $\mathrm{m}^{3} / \mathrm{s}$ lebih kecil dari debit banjir rencana sebesar $73.708 \mathrm{~m}^{3} / \mathrm{s}$ sehingga saluran tidak dapat menampung debit banjir di kala ulang 100 tahun. Maka dari itu saluran tersebut harus dilakukan adjustment dengan cara memperlebar dimensi dari saluran sungai tersebut sebagai upaya mitigasi struktural. Visualisasi profil muka air menggunakan perangkat lunak HEC-RAS pada kala ulang 10 tahun, 25 tahun, 50 tahun dan 100 tahun, 500 tahun, 1000 tahun terlihat pada Gambar 8.

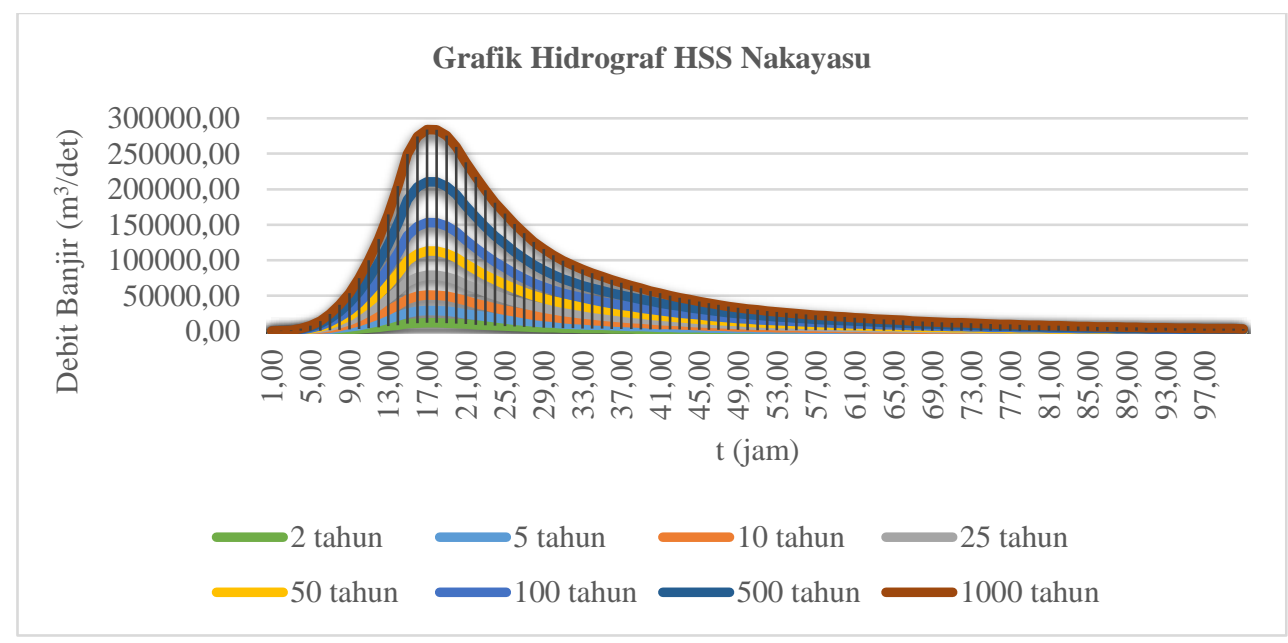

Gambar 7 Hidrograf HSS Nakayasu

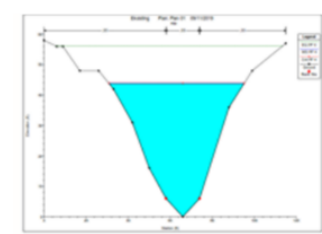

(a)

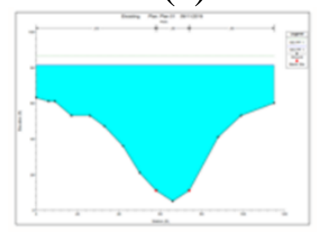

(d)

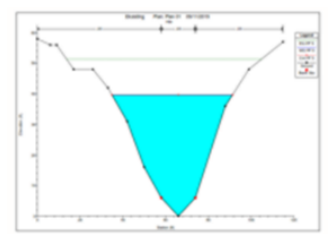

(b)

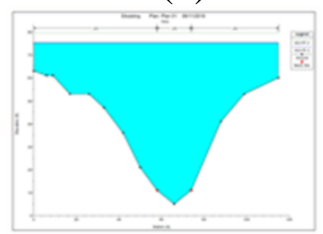

(e)

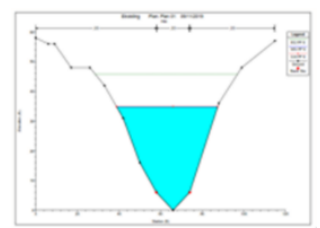

(c)

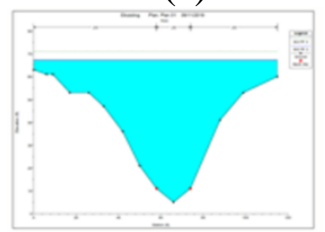

(f)

Gambar 8 Potongan melintang saluran eksisting pada kala ulang (a) 10, (b) 25, (c) 50, (d) 100, (e) 500, dan (f) 1000 Tahun

Mitigasi Banjir Struktural Menggunakan Model Hec-Ras dan Geo-Studio Pada Wilayah Sungai Toba-Asahan, Sumatera Utara - Rian Mantasa Salve Prastica, Aditya Widyatmoko, Rezky Kurniawan 
Normalisasi kemudian dilakukan sebagai skenario pemodelan penanganan banjir di sungai tinjauan. Setelah adanya pelebaran dimensi saluran, maka hasil simulasi profil muka aliran menggunakan software HEC-RAS dapat dilihat pada Gambar 9.

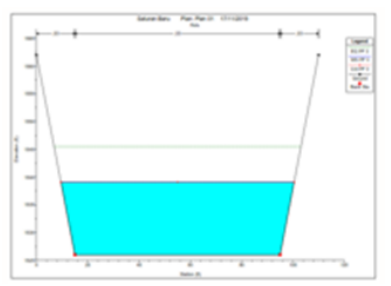

(a)

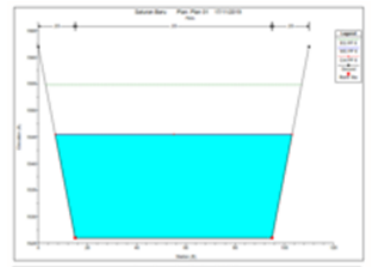

(d)

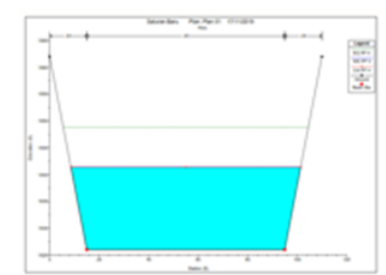

(b)

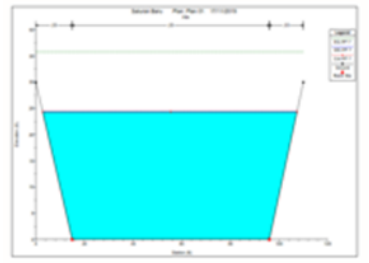

(e)

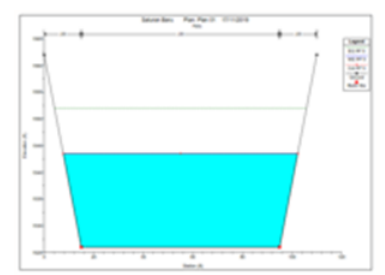

(c)

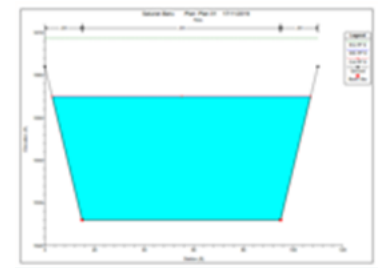

(f)

Gambar 9 Potongan melintang saluran setelah skenario normalisasi sungai pada kala ulang (a) 10, (b) 25, (c) 50, (d) 100, (e) 500, dan (f) 1000 Tahun

Berdasarkan hasil simulasi, terlihat bahwa normalisasi dapat melakukan reduksi limpasan banjir. Rata-rata penurunan limpasan yang terjadi dari kondisi eksisting ke kondisi normalisasi adalah 50\%.

Selain analisis kapasitas tampungan sungai, analisis stabilitas lereng sungai dilakukan menggunakan data tanah sekunder daerah studi menggunakan perangkat lunak Geo-Studio pada fitur SLOPE/W (Rousseau, Van de Wiel and Biron, 2017). Gambar 10 merupakan tampang melintang topografi Sungai Silau yang menjadi tinjauan penelitian ini. Setelah dilakukan input data tanah pada program, maka hasil safety factor untuk kondisi eksisting dan kondisi skenario setelah normalisasi dapat dilihat pada Gambar 11. Berdasarkan hasil analisis, skenario normalisasi menjanjikan kondisi yang ideal di mana safety factor lereng naik dari kondisi eksisting sebesar 0,972 menjadi 2,320 atau terjadi peningkatan sebesar $139 \%$. Sehingga, perbaikan lereng dengan skenario ini dinyatakan berhasil dan signifikan.

Hasil analisis kapasitas hidrolika sungai dan stabilitas lereng menunjukkan bahwa skenario mitigasi struktural berupa normalisasi sungai dapat menangani banjir secara efektif. Meskipun terlihat sebagai skenario yang mudah dalam melakukan pengendalian banjir, normalisasi sungai memiliki beberapa kelemahan yang perlu menjadi pertimbangan bagi policy maker dalam menentukan skenario yang efektif dalam penanganan banjir di daerah studi.

Dalam melakukan suatu keputusan penanganan bencana, pemerintah memerlukan rencana anggaran biaya yang perlu dialokasikan. Bila pengendalian banjir hanya mengandalkan mitigasi struktural, maka pemerintah akan mengeluarkan biaya besar (Prastica, Apriatresnayanto and Marthanty, 2019). Terlebih lagi, bila mitigasi struktural ini akan berkelanjutan dari waktu ke waktu tanpa mitigasi non-struktural di daerah tinjauan.

Mitigasi Banjir Struktural Menggunakan Model Hec-Ras dan Geo-Studio Pada Wilayah Sungai Toba-Asahan, Sumatera Utara - Rian Mantasa Salve Prastica, Aditya Widyatmoko, Rezky Kurniawan 


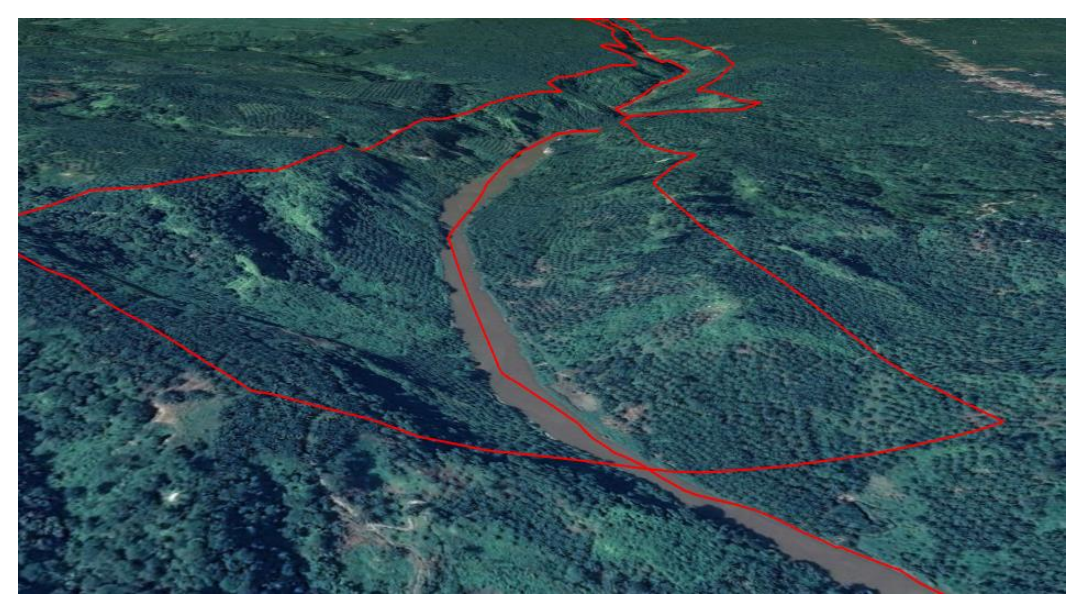

Gambar 10 Topografi Sungai Silau

Sumber: Google Earth, 2021

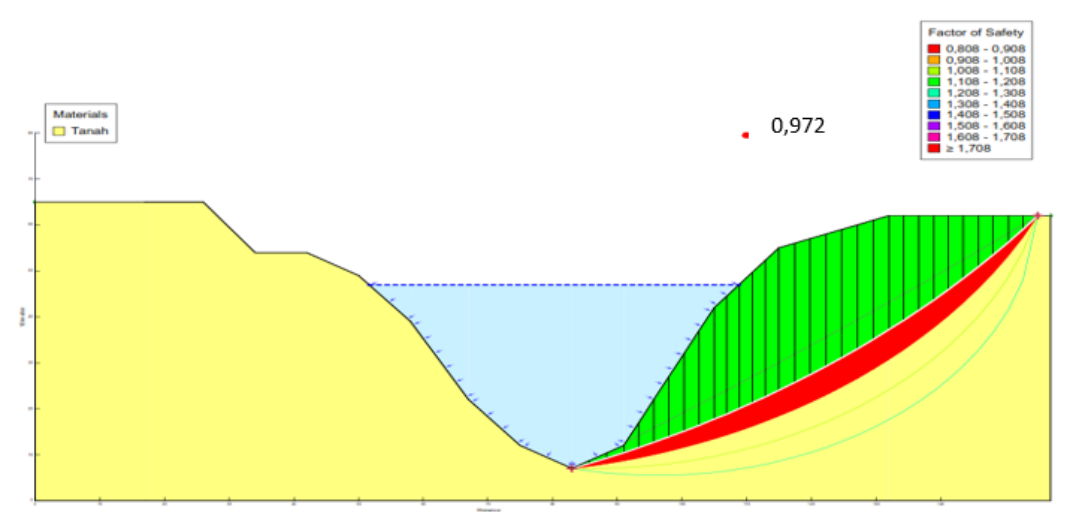

(a)

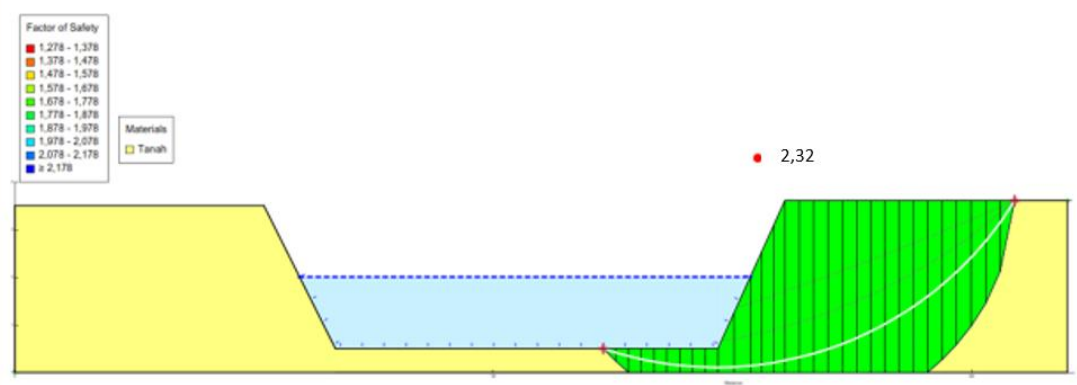

(b)

Gambar 11 Stabilitas lereng menggunakan Software Geo-Studio SLOPE/W pada kondisi (a) eksisting dan (b) skenario normalisasi sungai

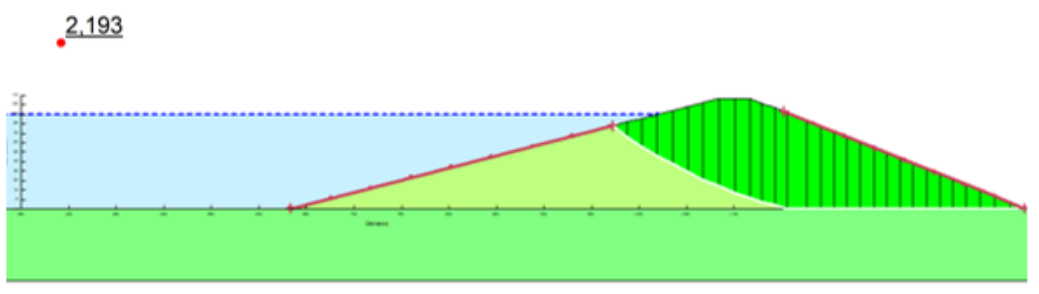

Gambar 12 Usulan desain bendungan urugan di daerah studi

Mitigasi Banjir Struktural Menggunakan Model Hec-Ras dan Geo-Studio Pada Wilayah Sungai Toba-Asahan, Sumatera Utara - Rian Mantasa Salve Prastica, Aditya Widyatmoko, Rezky Kurniawan 
Mitigasi non-struktural yang dimaksud adalah sosialiasi atau penambahan kapasitas masyarakat dalam menangani dan mencegah bencana banjir seperti wawasan infrastruktur hijau seperti pembuatan biopori dan konservasi lahan (Mohamed and Worku, 2020), pentingnya sistem pemanen air hujan (Guven and Tanik, 2018), dan upaya konservasi lain yang dapat dilakukan mandiri oleh masyarakat (Abon, David and Tabios, 2012). Peningkatan kapasitas masyarakat ini dapat membuat program pengendalian banjir berkelanjutan yang dapat dilakukan secara mandiri oleh komunitas. Adanya infrastruktur hijau yang dibuat oleh komunitas juga akan mereduksi limpasan banjir yang terjadi pada daerah tinjauan. Dengan adanya strategi manajemen ini, maka alokasi mitigasi struktural dapat dioptimumkan berdasarkan rencana anggaran biaya yang tersedia pada tahun itu. Bila banyak daerah yang perlu dilakukan mitigasi bencana berupa upaya struktural, maka perlu adanya skala prioritas daerah yang dapat diterapkan tiap tahunnya (Setyoasri and Prastica, 2020). Sehingga, pada rentang waktu tertentu, target mitigasi struktural dapat tercapai.

Opsi lain mitigasi struktural adalah pembangunan bendungan (Lempérière, 2017; Shole and Belayneh, 2019). Namun, ini juga perlu waktu pembangunan yang lama, alokasi dana yang besar, dan adanya kemungkinan konflik horizontal maupun vertikal yang dapat terjadi. Usulan bendungan pada penelitian ini berada di hulu Sungai Silau dan disesuaikan dengan karakteristik topografi daerah tersebut. Gambar 12 merupakah hasil usulan desain bendungan. Tujuan dari adanya usulan desain bendungan ini adalah untuk melihat reduksi banjir yang dapat terjadi dengan adanya bendungan di daerah studi. Berdasarkan analisis flood routing yang terjadi, sesuai dengan Gambar 13, reduksi banjir yang dapat terjadi adalah sebesar 24,83\%.

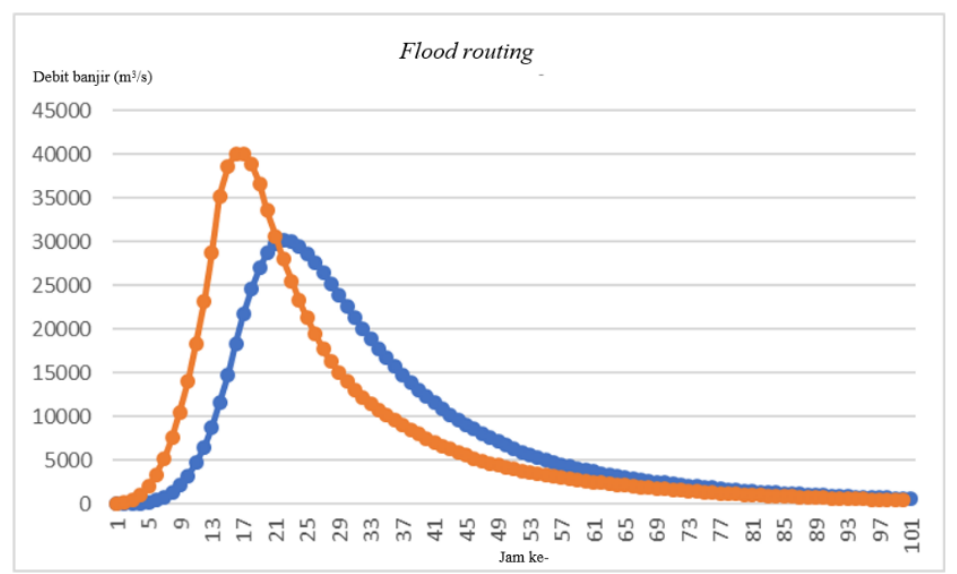

Gambar 13 Flood routing dengan adanya usulan bendungan did aerah studi

\section{Kesimpulan dan Saran}

\subsection{Kesimpulan}

Mitigasi struktural sebagai strategi pengendalian banjir dinilai signifikan dalam pengendalian banjir karena dapat mengakomodasi permasalahan kapasitas saluran dan stabilitas lereng. Hal ini dapat dianalisis melalui hasil skenario mitigasi struktural pada koridor sungai dengan meningkatnya kapasitas sungai dan faktor keamanan lereng yang terjadi. Sehingga, normalisasi sungai pada daerah studi bisa dilakukan. Begitu pula mitigasi struktural bila akan dibangun bendungan. Reduksi banjir juga dapat dilakukan pada daerah studi. Namun, dengan anggaran pemerintah 
sebagai pemangku kepentingan utama dalam pengendalian banjir, pengandalan single factor pada mitigasi struktural dinilai kurang baik, sehingga perlu adanya pertimbangan mitigasi non-struktural agar upaya mitigasi bencana banjir di daerah studi dapat dilakukan secara optimum.

\subsection{Saran}

Penelitian selanjutnya dalam strategi manajemen banjir perlu mempertimbangkan mitigasi struktural dan non-struktural yang dapat disimulasikan menjadi beberapa skenario sehingga dapat dianalisis model seperti apa yang dapat memberikan dampak optimum kepada lingkungan, tetapi juga dapat dilaksanakan oleh banyak pemangku kepentingan, baik pemerintah maupun masyarakat daerah.

\section{Ucapan Terima Kasih}

Penelitian ini dapat terlaksana atas bantuan fasilitas Laboratorium Hidrolika dan Bangunan Air, Departemen Teknik Sipil, Universitas Gadjah Mada. Penelitian ini didukung penuh oleh Hibah Peningkatan Kapasitas Dosen Muda Direktorat Penelitian Universitas Gadjah Mada Tahun 2021 Nomor 2458/UN1/DITLIT/DITLIT/PT/2021.

\section{Daftar Kepustakaan}

Abdi, R., Endreny, T. and Nowak, D, 2020. A model to integrate urban river thermal cooling in river restoration. Journal of Environmental Management. Elsevier Ltd, 258(July 2019), p. 110023. doi: 10.1016/j.jenvman.2019.110023.

Abon, C. C., David, C. P. C. and Tabios, G. Q, 2012. Community-based monitoring for flood early warning system: An example in central Bicol River basin, Philippines. Disaster Prevention and Management, 21(1), pp. 85-96. doi: 10.1108/09653561211202728.

Alam, A. et al, 2018. Flood risk assessment of Srinagar city in Jammu and Kashmir, India. International Journal of Disaster Resilience in the Built Environment, 9(2), pp. 114-129. doi: 10.1108/IJDRBE-02-2017-0012.

Andersen, D. C. et al, 2011. Managed flood effects on beaver pond habitat in a desert riverine ecosystem, bill williams river, Arizona USA. Wetlands, 31(2), pp. 195-206. doi: 10.1007/s13157-011-0154-y.

Balai Wilayah Sungai (BWS) II, 2013. Pola Pengelolaan Sumber Daya Air Wilayah Sungai Toba Asahan. pp. 1-115.

Bang, H., Miles, L. and Gordon, R, 2019. Evaluating local vulnerability and organisational resilience to frequent flooding in Africa: the case of Northern Cameroon. Foresight, 21(2), pp. 266-284. doi: 10.1108/FS-06-2018-0068.

Mitigasi Banjir Struktural Menggunakan Model Hec-Ras dan Geo-Studio Pada Wilayah Sungai Toba-Asahan, Sumatera Utara - Rian Mantasa Salve Prastica, Aditya Widyatmoko, Rezky Kurniawan 
Braga, A. et al, 2018. Performance of two advanced rainwater harvesting systems in Washington DC. Water (Switzerland), 10(5), pp. 1-13. doi: 10.3390/w10050667.

Broekhuizen, I. et al, 2019. Urban drainage models for green areas : Structural differences and their effects on simulated runoff. Journal of Hydrology X. Elsevier, 5(October), p. 100044. doi: 10.1016/j.hydroa.2019.100044.

Chow, V. Te et al, 1998. Applied Hydrology. pp. 1-294. Available at: http://ponce.sdsu.edu/Applied_Hydrology_Chow_1988.pdf.

Cojoc, G. M., Romanescu, G. and Tirnovan, A, 2015. Exceptional floods on a developed river: case study for the Bistrita River from the Eastern Carpathians (Romania). Natural Hazards. Springer Netherlands, 77(3), pp. 1421-1451. doi: 10.1007/s11069-014-1439-2.

Dinas Tata Kota Kabupaten Asahan, 2012. Laporan Akhir Penyusunan DED Drainase Primer di Kota Kisaran. Medan.

Ezzine, A. et al, 2020. Flood mapping using hydraulic modeling and Sentinel-1 image: Case study of Medjerda Basin, northern Tunisia. Egyptian Journal of Remote Sensing and Space Science. National Authority for Remote Sensing and Space Sciences, 23(3), pp. 303-310. doi: 10.1016/j.ejrs.2020.03.001.

Farooq, M., Shafique, M. and Khattak, M. S, 2019. Flood hazard assessment and mapping of River Swat using HEC-RAS 2D model and high-resolution 12m TanDEM-X DEM (WorldDEM). Natural Hazards. Springer Netherlands, 97(2), pp. 477-492. doi: 10.1007/s11069-019-03638-9.

Frans, J. H. and Halema, E. U. M, 2019. Analisis Parameter Alfa Hidrograf Satuan Sintetik Nakayasu Pada Das Di Pulau Flores. Jurnal Teknik Sipil, 8(2), pp. 227-240.

GEO-SLOPE International Ltd, 2012. Stability Modeling with SLOPE / W. July 2012. Calgary, Alberta, Canada: GEO-SLOPE International Ltd. Available at: www.geo-slope.com.

Guven, H. and Tanik, A, 2018. Water-energy nexus: Sustainable water management and energy recovery from wastewater in eco-cities. Smart and Sustainable Built Environment, 9(1), pp. 54-70. doi: 10.1108/SASBE-07-2017-0030.

Harahap, R, 2013. Penentuan Indeks Banjir sebagai Peringatan Siaga Berdasarkan Analisis Debit pada Sungai Asahan. Jurnal Saintika, 14(2), pp. 109-118.

Kumar, N. et al, 2019. Applicability of HEC - RAS 2D and GFMS for flood extent mapping : a case study of Sangam area, Prayagraj, India. Modeling Earth Systems and Environment. Springer International Publishing, (0123456789). doi: 10.1007/s40808-019-00687-8.

Lempérière, F, 2017. Dams and Floods. Engineering. Elsevier LTD on behalf of Chinese Academy of Engineering and Higher Education Press Limited Company, 3(1), pp. 144-149. doi: 10.1016/J.ENG.2017.01.018.

Lin, E., Shaad, K. and Girot, C, 2016. Developing river rehabilitation scenarios by integrating landscape and hydrodynamic modeling for the Ciliwung River in Jakarta, Indonesia. Sustainable Cities and Society. Elsevier B.V., 20, pp. 180-198. doi: 10.1016/j.scs.2015.09.011.

Lukman, A, 2017. Penelusuran Kawasan Daerah Aliran Sungai ( DAS ) Asahan. Buletin Utama Teknik, 13(1), pp. 49-54.

Mitigasi Banjir Struktural Menggunakan Model Hec-Ras dan Geo-Studio Pada Wilayah Sungai Toba-Asahan, Sumatera Utara - Rian Mantasa Salve Prastica, Aditya Widyatmoko, Rezky Kurniawan 
Mohamed, A. and Worku, H, 2020. Urban land cover and morphometric analysis for flash flood vulnerability mapping and riparian landscape conservation in Kebena River watershed, Addis Ababa. Applied Geomatics. Applied Geomatics. doi: 10.1007/s12518-020-00318-3.

Mohit, M. A. and Sellu, G. M, 2013. Mitigation of Climate Change Effects through Non-structural Flood Disaster Management in Pekan Town, Malaysia. Procedia - Social and Behavioral Sciences. Elsevier B.V., 85, pp. 564-573. doi: 10.1016/j.sbspro.2013.08.385.

Piotrowski, A. P., Osuch, M. and Napiorkowski, J. J, 2019. Joint Optimization of Conceptual Rainfall-Runoff Model Parameters and Weights Attributed to Meteorological Stations. Water Resources Management, 33(13), pp. 45094524. doi: 10.1007/s11269-019-02368-8.

Prastica, R. M. S., Apriatresnayanto, R. and Marthanty, D. R, 2019. Structural and green infrastructure mitigation alternatives prevent Ciliwung River from water-related landslide. International Journal on Advanced Science, Engineering and Information Technology, 9(6), pp. 1825-1832.

Price, R. K. and Vojinovic, Z, 2008. Urban food disaster management. Urban Water Journal, 5(3), pp. 259-276. doi: 10.1080/15730620802099721.

Rousseau, Y. Y., Van de Wiel, M. J. and Biron, P. M, 2017. Simulating bank erosion over an extended natural sinuous river reach using a universal slope stability algorithm coupled with a morphodynamic model. Geomorphology. Elsevier B.V., 295, pp. 690-704. doi: 10.1016/j.geomorph.2017.08.008.

Rubinato, M. et al, 2019. Urban and river flooding: Comparison of flood risk management approaches in the UK and China and an assessment of future knowledge needs. Water Science and Engineering. Elsevier Ltd, 12(4), pp. 274-283. doi: 10.1016/j.wse.2019.12.004.

Saputra, A. A., Saputro, D. D. and Prastica, R. M. S, 2021. Initial investigation of hydraulics engineering for flood mitigation: A case study in Krueng Aceh Sub-watershed. in IOP Conference Series: Earth and Environmental Science. doi: 10.1088/1755-1315/622/1/012002.

Setyoasri, Y. P. and Prastica, R. M. S, 2020. Rapid assessment of river watershed health and vulnerability level for restoration strategy: A study of river systems in Indramayu, West Java, Indonesia. IOP Conference Series: Earth and Environmental Science, 423(1). doi: 10.1088/17551315/423/1/012016.

Shenava, N. and Shourian, M, 2018. Optimal Reservoir Operation with Water Supply Enhancement and Flood Mitigation Objectives Using an Optimization-Simulation Approach. Water Resources Management. Water Resources Management, 32(13), pp. 4393-4407. doi: 10.1007/s11269-0182068-4.

Shole, D. G. and Belayneh, M. Z, 2019. The effect of side slope and clay core shape on the stability of embankment dam: Southern Ethiopia. International Journal of Environmental Science and Technology. Springer Berlin Heidelberg, 16(10), pp. 5871-5880. doi: 10.1007/s13762-019-02228-3.

Stephenson, V., Finlayson, A. and Morel, L. M, 2018. A risk-based approach to shelter resilience following flood and typhoon damage in rural Philippines. Geosciences (Switzerland), 8(2). doi: 10.3390/geosciences8020076.

Mitigasi Banjir Struktural Menggunakan Model Hec-Ras dan Geo-Studio Pada Wilayah Sungai Toba-Asahan, Sumatera Utara - Rian Mantasa Salve Prastica, Aditya Widyatmoko, Rezky Kurniawan 
Sukmana, A. et al, 2013. Bencana Mengepung, Selamatkan DAS Asahan! Kabupaten Simalungun, Sumatera Utara. Kementerian Kehutanan, Badan Penelitian dan Pengembangan Kehutanan.

Wedawatta, G. et al, 2016. Disaster risk reduction infrastructure requirements for South-Western Bangladesh: Perspectives of local communities. Built Environment Project and Asset Management, 6(4), pp. 379-390. doi: 10.1108/BEPAM-06-2015-0022.

Zevri, A. and Isma, F, 2021. Studi Keseimbangan Air (Water Balanced) Daerah Aliran Sungai Asahan. Teras Jurnal, 11(1), pp. 1-16.

Zhao, Y., Tong, Z.-Y. and Lü, Q, 2014. Slope Stability Analysis Using Slice-Wise Factor of Safety. Mathematical Problems in Engineering, 2014, pp. 1-6. Available at: https://econpapers.repec.org/RePEc:hin:jnlmpe:712145. 